\title{
Internal branding with corporate ethical values and corporate social responsibility: The case of the life insurance industry in Taiwan
}

\author{
C-S. Lai and K-T. Hsu * \\ Department of International Business \\ National Taichung University of Education, Taichung, Taiwan, ROC \\ *To whom all correspondence should be addressed \\ kthsu@mail.ntcu.edu.tw
}

\begin{abstract}
The purpose of this study is to identify the extent to which corporate ethical values and employee-oriented CSR can be employed as business levers of internal branding for the life insurance industry. Our results indicate that the impact of corporate ethical values on internal branding benefits is fully mediated by knowledge dissemination, and that the impact of employee-based CSR on internal branding benefits is partially mediated by knowledge dissemination. Therefore, for life insurance companies, employee-oriented CSR can be considered an independent lever of internal branding and can be conducted without other auxiliary initiatives to induce internal branding benefits.
\end{abstract}

\section{Introduction}

For the financial services industry "what is delivered is less important than how it is delivered" (de Chernatony \& Cottam, 2006: 616), because services are essentially intangible and do not result in ownership of anything (Papasolomou \& Vrontis, 2006). One important precondition of sustainable competitive advantages for a financial services company is that all employees in the organization are involved in the delivery of service quality throughout the service-profit chain (Ahmed \& Rafig, 2003; Heskett, Jones, Loveman, Sasser, \& Schlesinger, 1994). For the life insurance industry this precondition is more decisive than other financial services sectors. Life insurance policies are complex and trust-based services (Schlager, Bodderas, Maas \& Cachelin, 2011), and require more interactions between employees, especially salespeople and customers, than other financial services. The life insurance industry is thus a good example of a service intensive sector.

Branding initiatives primarily focus on external stakeholders such as customers (Aurand, Gorchels \& Bishop, 2005). Recent research has increasingly suggested that employees play a decisive role in branding (Ind, 2003). Internal branding aims at creating the right type of environment in which employees are encouraged to create, coordinate and improve the entire business, and in which behaviors enhancing service quality and brand become a reflexive part of employee action (Ahmed \& Rafig, 2003). Competitive advantage of a life insurance company is derived from this environment and the accompanying performance enhancing behaviors.

In the present study, we try to incorporate corporate ethical values (CEV) and employee-oriented corporate social responsibility (CSR) in internal branding for the life insurance industry. First, all cognitive activities of employees are shaped by the corporate culture and by the organizational context in which they occur (Galotti, 2008). CEV is a major component of corporate culture (Schein, 1984). Therefore, this study incorporates CEV in the internal branding literature. In the face of recent corporate scandals in the financial services industry, more attention has been focused on CEV in recent years (Mostovicz, Kakabadse \& Kakabadse, 2009). Second, internal branding assumes that in order to improve internal processes continuously, management has to plan and build appropriate and close relationships with internal parties (Ahmed \& Rafig, 2003). For this reason, to establish a "high contract partnership" with employees through CSR towards employees may be the first step towards external branding benefits. A refined and renamed construct, i.e. employeeoriented CSR, is thus introduced to internal branding literature in the current study. According to Maignan, Ferrell \& Hult (1999), CSR is a construct with four facets, i.e. economic, legal, discrcetionary, and ethical responsibilities. The target stakeholders may be employees, customers, or public stakeholders. The responsibilities that seek to look after the needs of employees and to improve reciprocal exchange relationships between the organization and employees are referred to as employee-oriented CSR in the current study.

The purpose of this study is to identify the extent to which CEV and employee-oriented CSR can be employed as business levers of internal branding. Several proposed relationships which have not been fully explored in the previous literature are to be accessed. These are the relationships between CEV, employee-oriented CSR and organizational benefits resulting from internal branding. 


\section{Literature review}

\section{Internal branding}

Recent research has increasingly discovered that internal branding is important for the success of a company (Burmann \& König, 2011; Tomczak, Herrmann, Brexendorf \& Kernstock, 2005). The four terms internal branding, internal brand management, employee branding and internal marketing have been used to describe these activities and programs (Aurand et al., 2005). For the sake of parsimony, the term internal branding will be used through the remainder of this study.

Successful branding can provide a sustainable competitive advantage. A brand is considered to be a cluster of functional and emotional benefits (King \& Grace 2010) which evolve through various forms of interaction, including customer-customer, employee-customer, and company-customer interactions (Merz, He \& Vargo, 2009; Schlager et al., 2011). Some of these interactions are not under the influence of the company, e.g. employee-customer interactions (Schlager et al., 2011).

Within such a context, internal branding emphasizes the role played by employees for branding (Burmann \& König, 2011; Nguyen \& Leblanc, 2002). Past studies have recognized the fact that the delivery of service quality, and subsequent customer experiences depend on employee behavior and attitudes during interactions (Schlager et al., 2011; Vella, Gountas \& Walker, 2009). As a service intensive industry, the life insurance industry should focus on managing attitudes and behaviors of employees appropriately (Pugh, 2001). Thus, the ultimate goal of internal branding is to direct employees to positive brandrelated outcomes reflecting organizational requirements (King \& Grace, 2010). In the current study, these outcomes are termed as internal branding benefits.

\section{Corporate ethical values}

CEV is a major component of corporate culture (Schein, 1984) and is referred to the cultural characteristics of an ethical context (Valentine, Godkin \& Lucero, 2002). Among values which companies may have, $\mathrm{CEV}$ play a special role. $\mathrm{CEV}$ is an organizational environment, influencing thoughts and feelings, and guiding behaviour of individuals within the organization (Baker, Hunt \& Andrews, 2006). They underpin other values that guide product or service quality and treatment received by customers, for instance, seeing as CEV establishes the standards in terms of which business action can be judged 'right' or 'wrong' (Bendixen \& Abratt, 2007; Hunt, Wood \& Chonko, 1989).

The superior performance of some corporations is to some extent attributable to the unique values shared by their members (Hunt et al., 1989). The links between CEV and employee performance or other favorable outcomes justify the assertion that CEV can be used as a potentially fruitful business practice within the context of internal branding.
One necessary condition for internal branding to establish, develop and maintain successful reciprocal exchange relationships is trust, and specifically trust in the "rules of the game" maintained in the organization (Ahmed \& Rafig, 2003). Such links between the employees and their organization built on trust are to some degree enhanced by the ethical environment (Valentine et al., 2002).

\section{Employee-oriented CSR}

CSR can positively affect stakeholder attitudes toward their company (Lichtenstein, Drumwright \& Braig, 2004). Correspondingly, the activities and practices representative of CSR that look after the needs of employees can positively influence employee attitudes and even their behaviors within the organization. Most research about CSR has focused on external stakeholders, especially customers. CSR is a core component of branding from the viewpoint of customers (Beneke, Wannke, Pelteret, Tlaid \& Gordon, 2012). How employees are motivated through employee-oriented CSR to develop their internal branding outcomes and the corresponding organizational benefits, is less investigated in the previous literature (Maignan \& Ferrell, 2001; Rego, Leal, Cunha, Faria \& Pinho, 2010). In the present study we explore the possibility of CSR as one lever of internal branding, i.e. as one lever that focuses on employees to induce favorable attitudes and behaviors of employees.

Maignan et al. (1999) proposed a widely adopted conceptualization and operationalization of CSR. CSR was defined as "the extent to which businesses meet economic, legal, discretionary and ethical responsibilities placed on them by their various stakeholders (Maignan et al., 1999: 457)." Three primary stakeholder groups were taken into account in developing the CSR scale: employees, consumers and public stakeholders. Discretionary responsibilities were defined as the extent to which "businesses get actively involved in the betterment of society (Maignan et al., 1999: 457)." The activities and behaviors representative of discretionary responsibilities towards employees reflect how far the organization concretely treats its employees like human beings and improves this treatment. In the present study we term them "employee-oriented CSR". In essence employee-oriented CSR is therefore an ethical matter and subsequently linked to CEV to a certain extent. However, employee-oriented CSR can be conceptually and statistically discriminated from $\mathrm{CEV}$.

\section{Conceptual framework}

A path model highlighting associations among CEV, CSR, knowledge dissemination, and organizational benefits will be tested to further elucidate how an ethical environment and employee-oriented CSR influence internal branding outcomes. The framework of our model postulates a causal chain that leads from CEV and CSR via knowledge dissemination to internal branding benefits (Figure 1). 


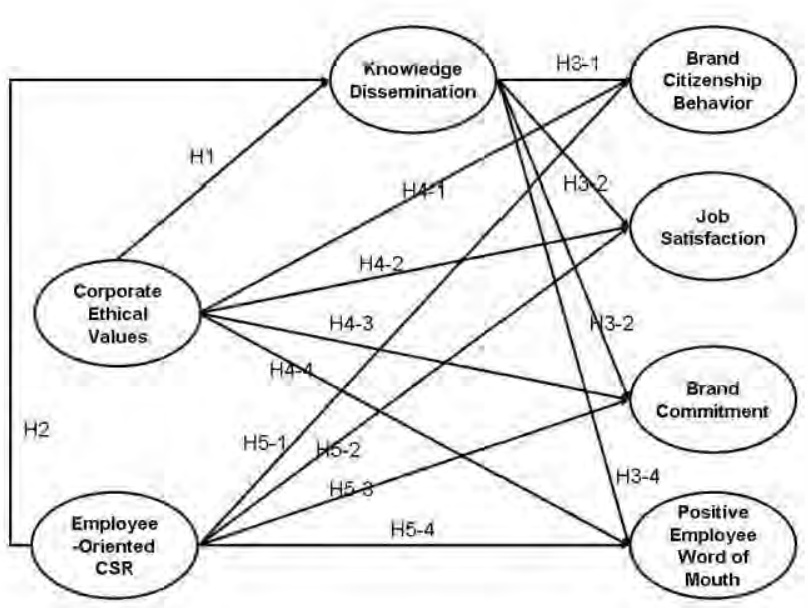

Figure 1: Conceptual model

CEV guarantees trust in the "rules of the game" maintained in the organization (Ahmed \& Rafig, 2003). This is a critical precondition for successfully transferring brand knowledge to individuals within the organization, and further for successful internal branding and external branding. Without such relationships, knowledge dissemination regarding branding is unimaginable. Therefore, we hypothesize that (see Figure 1):

\section{H1: CEV is positively related to knowledge dissemination.}

The reciprocal exchange relationships between organization and employees are precondition for knowledge dissemination. Such relationships ensure the success of the transfer of brand-related information from organization to employees and the development of employee brand knowledge (King \& Grace, 2010). Creating an environment that fosters these social-emotional and material relationships can enhance knowledge dissemination. Employee-oriented CSR seeks to look after the needs of employees and concretizes the relational considerations necessary for successful exchanges between the organization and employees. Therefore, we hypothesize that (see Figure 1):

\section{H2: Employee-oriented CSR is positively related to knowledge dissemination.}

There may be numerous possible favorable internal branding outcomes. However, only those internal branding benefits that are most observed and have direct effects on external branding are selected for the current study. Therefore, we select brand citizenship behavior, job satisfaction, brand commitment, and positive employee word of mouth as internal branding benefits for the current study (cf. Burmann \& König, 2011; Burmann, Zeplin \& Riley, 2009; King \& Grace, 2010).

Employees' brand citizenship behavior may be the best manifestation of their active engagement and can be viewed as an organizational benefit derived from internal branding (Keller, 2001; King \& Grace, 2010). Job satisfaction of employee results from internal support services and policies that lead to positive organizational and brand-related behaviors and enable employees to deliver brand-related values to customers (Heskett, Jones, Loveman, Sasser \& Schlesinger, 1994). Based on the service-profit chain, job satisfaction is considered to be an important component of internal branding benefits. Brand commitment influences employees' willingness to exert efforts towards reaching the brand goals (Burmann \& König, 2011). Because of the direct link with job satisfaction (Ramlall, 2004), brand commitment is also a component of internal branding benefits (King \& Grace, 2010). Satisfied employees may also be more likely to engage in positive word-of-mouth communication with friends and customers (Miles \& Mangold, 2004). Positive employee word of mouth can enhance external outcomes and is thus one constituent of internal branding benefits.

To ensure employees are able to meet organizational requirements and deliver the brand promise, initially, brandrelated information should be transferred from the organization to its employees. Through the transfer of this information, employee behaviors can be modified (Kessler, Undy \& Heron, 2004; Robson \& Tourish, 2005) and aligned with organizational goals (Guest \& Conway, 2002). Knowledge dissemination results in employee brand knowledge that enables the attraction, retention and motivation of employees to deliver the brand promise (King $\&$ Grace, 2010). The impact of knowledge dissemination on our four internal branding benefits is identified by many previous studies (Burmann \& König, 2011; Jones, Busch \& Dacin, 2003; King \& Grace, 2010). Therefore, we hypothesize that (see H3-1 to H3-4 in Figure 1):

\section{H3: Knowledge dissemination is positively related to internal branding benefits.}

The psychological contract is central to the relationship between the employee and the employer (Valentine et al., 2002). A reciprocal exchange relationship such as the psychological contract is based on trust in the "rules of the game" maintained between employees and the organization, which in turn is guaranteed by CEV (Ahmed \& Rafig, 2003). Companies can create such an environment by supporting ethical conduct to strengthen the psychological contract (Valentine et al., 2002) and derive internal branding benefits. The positive influence of $\mathrm{CEV}$ on some internal branding benefits has been confirmed by previous research (Sims, 1991; Valentine et al., 2002). Thus, we hypothesize that (see H4-1 to H4-2 in Figure 1):

\section{H4: $C E V$ is positively related to internal branding benefits.}

The brand-related organizational benefits are attained through an exchange process between the employee and the organization (Aselage \& Eisenberger, 2003). Only when the organization treats employees appropriately is the attainment of brand-related organizational benefits likely to be realized. Empirically, the positive impacts of CSR on organizational commitment and business performance are 
supported by the results of Maignan et al. (1999) and CoyleShapiro \& Morrow (2006). Therefore, we hypothesize (see H5-1 to H5-2 in Figure 1):

\section{H5: Employee-oriented CSR is positively related to internal branding benefits.}

\section{Methodology}

\section{Data collection}

The aim of the sampling plan was to gather salesperson responses from major life insurance companies in Taiwan. Each participating organization was contacted by telephone to determine if the sales manager would be willing to cooperate in the study. Questionnaires were sent to sales managers in each participating organization. The managers distributed a copy to the individual salespeople. To ensure confidentiality, respondents were asked to send completed surveys directly to the author. To ensure that the questionnaire was understood correctly, a pretest was conducted with sales manager and salespeople, and further refined the model and scales on the basis of the feedback received. Only some items needed to be rephrased for comprehensibility. A total of 800 survey instruments were distributed. Before analysis, items were examined through various SPSS 18 procedures for accuracy of data entry, missing values, and fit between distributions and the assumptions of structural equation modeling. Of the 596 returned questionnaires, 76 were discarded due to missing data. As a result of the sampling, 520 respondents formed the basis of this study's empirical analysis.

\section{Questionnaire design}

All measures are drawn from extant research. The CEV scale developed by Hunt et al. (1989) can provide information regarding how effective a company's ethics policies are and to what extent employees are aware of these policies (Richtermeyer, Greller \& Valentine, 2006). This scale originally consisted of five items. Two reversed items are deleted for their regression weights are lower than 0,5 (Fornell \& Larcker, 1981). This result is consistent with that of Hunt et al. (1989). The original scale of Maignan et al. (1999) to measure CSR includes seven items measuring economic responsibilities, seven items measuring legal responsibilities, seven items measuring ethical responsibilities, and eight items measuring discretionary responsibilities. Among these items, four items measuring discretionary responsibilities targeting employees, i.e. item 1 , 2,3 , and 4, are borrowed from the original scale of Maignan et al. (1999) to measure the employee-oriented CSR. Our scale to measure knowledge dissemination is a revised version of the scale developed by King \& Grace (2010). The original version includes seven items. Two items were deleted because the situations they describe happen seldom in Taiwanese life insurance companies. The seven-item scale of Burmann \& Zeplin (2005) was adapted for measuring brand citizenship behaviour. Two items are deleted since their regression weights are lower than 0,5
(Fornell \& Larcker, 1981). The scale developed by Hackman \& Oldham (1975) is used to measure job satisfaction. The six-item scale to measure brand commitment consists of four items drawn from Allen \& Meyer (1990) and two items borrowed from Mohr, Fisher \& Nevin (1996). The four-item scale of positive employee word of mouth is adapted from King \& Grace (2010). Responses to items about the relevant seven constructs used seven-point Likert scales anchored at $1=$ "strongly disagree" and 7 = "strongly agree".

\section{Results}

\section{Measurement model}

AMOS 16,0 (maximum likelihood estimation) was employed to complete our analysis. As illustrated in Table 1, the Cronbach's $\alpha$ of each construct is between 0,835 and 0,941 , demonstrating adequate internal consistency (Nunnally \& Bernstein, 1994). The composite reliability (CR) of all constructs is between 0,8557 and 0,9416 , indicating a favourable level of construct reliability (Bagozzi \& Yi, 1988; Fornell \& Larcker, 1981).

The average variance extracted (AVE) is between 0,5008 and 0,7635 , above the 0,5 benchmark recommended by Fornell \& Larcker (1981). All estimated regression weights of observed variables for the latent variables are significant at the 0,001 level and over 0,5 threshold. The measurement scales show strong convergent validity.

To examine discriminant validity, a procedure suggested by Torkzadeh, Koufteros, \& Pflughoeft (2003) and Fornell \& Larcker (1981) is employed. First, a model is built for each of the 21 possible paired correlations between the constructs. The model is then analyzed with the correlation between the constructs free to assume any value. The method of bootstrapping was employed to estimate the twotailed significance for the paired correlations. The number of bootstrap samples was set to be 1000 . Discriminant validity is achieved when the value of 1 is not included in the confidence interval (Bagozzi and Phillips, 1982). The results that for parsimony are not reported here support the discriminate validity of all measures.

Following Kline (2005) the current study employed the following five indices to evaluate model fit, i.e. the model chi-square $\left(\mathrm{X}^{2}\right)$, the normed chi-square $\left(\mathrm{X}^{2} / \mathrm{DF}\right)$, the Bentler comparative fit index (CFI), the standardized root mean square residual (SRMR) and the root mean square error of approximation (RMSEA) with its $90 \%$ confidence interval. Bollen (1989) suggested that values for $\mathrm{X}^{2} / \mathrm{DF}$ of less than 5,0 indicate reasonable fit. Hu \& Bentler (1999) suggest that CFI values higher than roughly 0,9 may indicate a reasonably good fit of the researcher's model. Values for the SRMR of less than 0,1 generally indicate favorable model fit (Kline, 2005). RMSEA values of less than 0,05 indicate good fit, values between 0,05 and 0,08 reasonable fit, and values higher than 0,1 suggest poor fit (Kline, 2005). 
Given that CEV is measured with only three items, the model for this construct is just-identified. Therefore, the CFA for this measure is not available. For employeeoriented CSR, values of selected fit indexes indicate favourable model fit.

For knowledge dissemination (KD), except for the $\mathrm{X}^{2}$ statistic, all other indexes indicate reasonable model fit. The $\mathrm{X}^{2}$ statistic of KD is statistically significant. However, this is inflated due to sample size (Jöreskog \& Sörbom, 1993). To address the sensitivity of the $\mathrm{X}^{2}$ statistic, we employ the normed chi-square $\left(\mathrm{X}^{2} / \mathrm{DF}\right)$. Using this approach, the value of $\mathrm{X}^{2} / \mathrm{DF}$ for $\mathrm{KD}$ is less than 5 and therefore within recommended tolerance (Bollen, 1989).

Just as KD, for brand citizenship behavior (BCB), job satisfaction (JS), brand commitment (BC), and positive employee word of mouth (PEWOM), except for the $\mathrm{X}^{2}$ statistic, all other indexes indicate reasonable model fit. The values of their $\mathrm{X}^{2} / \mathrm{DF}$ are all less than 5 , supporting overall model fit of these constructs.

Table 1: Reliability and validity tests of each scale

\begin{tabular}{|c|c|c|c|c|}
\hline Construct & Cronbach's A & $\mathrm{CR}$ & AVE & Model fit indexes \\
\hline CEV & 0,840 & 0,8624 & 0,6833 & N/A \\
\hline CSR & 0,921 & 0,9212 & 0,7451 & $\begin{array}{l}\mathrm{X} 2(2)=1,316 ; \mathrm{P}=0,518 ; \mathrm{X} 2 / \mathrm{DF}=0,658 ; \mathrm{CFI}=1,000 ; \mathrm{SRMR}=0,0042 \\
\mathrm{RMSEA}=0,000(0,000-0,077)\end{array}$ \\
\hline $\mathrm{KD}$ & 0,941 & 0,9416 & 0,7635 & $\begin{array}{l}\mathrm{X} 2(5)=18,680 ; \mathrm{P}=0,002 ; \mathrm{X} 2 / \mathrm{DF}=3,736 ; \mathrm{CFI}=0,994 ; \mathrm{SRMR}=0,0115 ; \\
\mathrm{RMSEA}=0,073(0,039-0,109)\end{array}$ \\
\hline$\overline{\mathrm{BCB}}$ & 0,912 & 0,917 & 0,6912 & $\begin{array}{l}\mathrm{X} 2(5)=11,226 ; \mathrm{P}=0,047 ; \mathrm{X} 2 / \mathrm{DF}=2,245 ; \mathrm{CFI}=0,997 ; \mathrm{SRMR}=0,0105 ; \\
\mathrm{RMSEA}=0,049(0,005-0,088)\end{array}$ \\
\hline JS & 0,878 & 0,8947 & 0,6836 & $\begin{array}{l}\mathrm{X} 2(2)=7,465 ; \mathrm{P}=0,024 ; \mathrm{X} 2 / \mathrm{DF}=3,732 ; \mathrm{CFI}=0,996 ; \mathrm{SRMR}=0,0139 ; \\
\mathrm{RMSEA}=0,073(0,023-0,131)\end{array}$ \\
\hline $\mathrm{BC}$ & 0,844 & 0,8557 & 0,5008 & $\begin{array}{l}\mathrm{X} 2(9)=27,684 ; \mathrm{P}=0,000 ; \mathrm{X} 2 / \mathrm{DF}=3,076 ; \mathrm{CFI}=0,984 ; \mathrm{SRMR}=0,0269 ; \\
\mathrm{RMSEA}=0,063(0,037-0,091)\end{array}$ \\
\hline PEWOM & 0,918 & 0,9253 & 0,7576 & $\begin{array}{l}\mathrm{X} 2(2)=8,465 ; \mathrm{P}=0,015 ; \mathrm{X} 2 / \mathrm{DF}=4,233 ; \mathrm{CFI}=0,996 ; \mathrm{SRMR}=0,0122 ; \\
\mathrm{RMSEA}=0,079(0,030-0,137)\end{array}$ \\
\hline
\end{tabular}

Following the two-step rule proposed by Bollen (1989), we re-specify the structural model as a CFA model (Kline 2005). Values of selected fit indexes indicate reasonable model fit, as reported in note of Table 1.

\section{Structural model}

For the structural model, values of selected fit indexes suggest reasonable model fit for the structural model, as reported in the note below Table 2. The effect decomposition is also presented in Table 2. We resort to these results to test the proposed hypotheses.
For the path leading from CSR to knowledge dissemination (CEC->KD), the standardized estimate of the total effect is 0,434 , statistically significant at the 0,01 level. This result supports H1. For the path leading from employee-oriented CSR to knowledge dissemination (CSR $>$ KD), the standardized estimate of the total effect is 0,460 , statistically significant at the 0,01 level. This result supports H2. As illustrated in Table 2 and Figure 2, for the path leading from knowledge dissemination to brand citizenship behavior, job satisfaction, brand commitment, and positive employee word of mouth (KD->BCB, KD->JB, KD->BC, and KD$>$ PEWOM), all estimated standardized regression weights are positive and statistically significant at the 0,01 level. As such, H3-1, H3-2, H3-3, and H3-4 are supported. 
Table 2: Effect decomposition

\begin{tabular}{|c|c|c|c|c|c|c|}
\hline & Unstandardized & Standardized & Unstandardized & Standardized & Unstandardized & Standardized \\
\hline & Direct effects & & Indirect effects & & Total effects & \\
\hline $\mathrm{CEV} \rightarrow \mathrm{KD}$ & $\begin{array}{c}0,428(<0,001) \\
\mathrm{SE}=0,050\end{array}$ & 0,434 & 0 & 0 & 0,428 & 0,434 \\
\hline $\mathrm{CSR}>\mathrm{KD}$ & $\begin{array}{c}0,341(<0,001) \\
\mathrm{SE}=0,034\end{array}$ & 0,460 & 0 & 0 & 0,341 & 0,460 \\
\hline $\mathrm{KD}->\mathrm{BCB}$ & $\begin{array}{c}0,409(<0,001) \\
\mathrm{SE}=0,050\end{array}$ & 0,550 & 0 & 0 & 0,409 & 0,550 \\
\hline $\mathrm{KD} \rightarrow \mathrm{JS}$ & $\begin{array}{c}0,385(<0,001) \\
\mathrm{SE}=0,083\end{array}$ & 0,308 & 0 & 0 & 0,385 & 0,308 \\
\hline $\mathrm{KD} \rightarrow \mathrm{BC}$ & $\begin{array}{c}0,363(<0,001) \\
\mathrm{SE}=0,059\end{array}$ & 0,427 & 0 & 0 & 0,363 & 0,427 \\
\hline $\begin{array}{l}\mathrm{KD}-> \\
\text { PEWOM }\end{array}$ & $\begin{array}{c}0,472(<0,001) \\
\mathrm{SE}=0,065\end{array}$ & 0,475 & 0 & 0 & 0,472 & 0,475 \\
\hline $\mathrm{CEV} \rightarrow \mathrm{BCB}$ & $\begin{array}{c}-0,036(0,342) \\
\mathrm{SE}=0,038\end{array}$ & $-0,049$ & $\begin{array}{l}0,175 \\
\text { Sobel } z=5,914\end{array}$ & 0,239 & 0,140 & 0,190 \\
\hline $\mathrm{CEV} \rightarrow \mathrm{JS}$ & $\begin{array}{c}-0,007(0,920) \\
\mathrm{SE}=0,071\end{array}$ & $-0,006$ & $\begin{array}{l}0,165 \\
\text { Sobel } z=4,078\end{array}$ & 0,134 & 0,158 & 0,128 \\
\hline $\mathrm{CEV} \rightarrow \mathrm{BC}$ & $\begin{array}{c}0,015(0,739) \\
\mathrm{SE}=0,045\end{array}$ & 0,018 & $\begin{array}{l}0,155 \\
\text { Sobel } z=4,996\end{array}$ & 0,185 & 0,170 & 0,203 \\
\hline $\begin{array}{l}\text { CEV -> } \\
\text { PEWOM }\end{array}$ & $\begin{array}{c}0,048(0,363) \\
\mathrm{SE}=0,053\end{array}$ & 0,049 & $\begin{array}{l}0,202 \\
\text { Sobel } z=5,537\end{array}$ & 0,206 & 0,250 & 0,255 \\
\hline $\mathrm{CSR} \rightarrow \mathrm{BCB}$ & $\begin{array}{c}0,189(<0,001) \\
\mathrm{SE}=0,031\end{array}$ & 0,344 & $\begin{array}{l}0,140 \\
\text { Sobel } z=6,339\end{array}$ & 0,253 & 0,329 & 0,597 \\
\hline CSR $>$ JS & $\begin{array}{c}0,438(<0,001) \\
\mathrm{SE}=0,057\end{array}$ & 0,474 & $\begin{array}{l}0,131 \\
\text { Sobel } z=4,210\end{array}$ & 0,142 & 0,570 & 0,616 \\
\hline $\mathrm{CSR} \rightarrow \mathrm{BC}$ & $\begin{array}{c}0,281(<0,001) \\
\mathrm{SE}=0,040\end{array}$ & 0,447 & $\begin{array}{l}0,124 \\
\text { Sobel } z=5,244\end{array}$ & 0,196 & 0,405 & 0,643 \\
\hline $\begin{array}{l}\text { CSR - } \\
\text { PEWOM }\end{array}$ & $\begin{array}{c}0,214(<0,001) \\
\mathrm{SE}=0,042\end{array}$ & 0,291 & $\begin{array}{l}0,161 \\
\text { Sobel } z=5,882\end{array}$ & 0,219 & 0,375 & 0,510 \\
\hline
\end{tabular}

Note: $\mathrm{X}^{2}(419)=1722,632(0,000), \mathrm{X}^{2} \mathrm{DF}=4,111, \mathrm{CFI}=0,908, \mathrm{SRMR}=0,0823$, and RMSEA $=0,077$, at the $90 \%$ confidence interval $0,074-0,081 . \mathrm{SE}=$ standard error. $\mathrm{P}$ values are in parentheses.

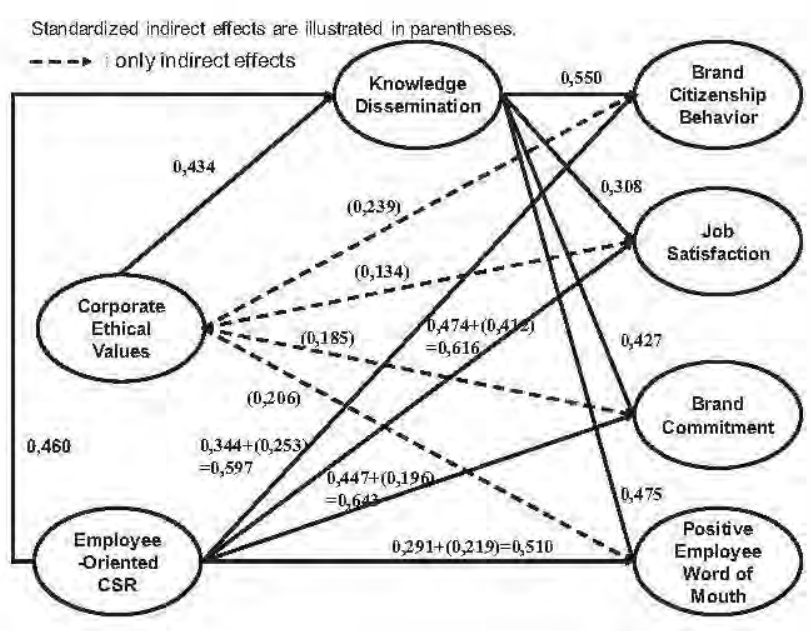

Figure 2: Results of structural model

The impact of CEV on internal branding benefits is decomposed into direct effects and indirect effects by way of knowledge dissemination. As shown in Table 2 and Figure 2, the direct effects of CEV on four internal branding benefits are statistically insignificant. To test the indirect effects, the Sobel test (Sobel, 1982), that is consistent with the procedures suggested by Baron \& Kenny (1986) and the most widely employed test of mediation effects, is conducted. The Sobel z values of all four indirect effects for the path from CEV to internal branding benefits (CEV$>\mathrm{BCB}, \mathrm{CEV} \rightarrow \mathrm{JB}, \mathrm{CEV}>\mathrm{BC}$, and $\mathrm{CEV} \rightarrow \mathrm{PEWOM}$ ) are greater than 1,96 , i.e. statistically significant. These results imply that the impact of CEV on internal branding benefits is fully mediated by knowledge dissemination (Andrews, Netemeyer, Burton, Moberg \& Christainsen, 2004; Baron \& Kenny, 1986; Holmbeck, 1997). The indirect effects of CEV on the four internal branding effects are positive. These results support $\mathrm{H} 4-1, \mathrm{H} 4-2, \mathrm{H} 4-3$, and $\mathrm{H} 4-4$.

Similarly, the influence of employee-oriented CSR on internal branding benefits is decomposed into direct effects and indirect effects by way of knowledge dissemination. In contrast to CEV, employee-oriented CSR has significant direct effect on internal branding benefits as illustrated in Table 2 and Figure 2. The Sobel $z$ values of all four indirect effects for the path from employ-based CSR to internal branding benefits ( $\mathrm{CSR}>\mathrm{BCB}, \mathrm{CSR}>\mathrm{JB}, \mathrm{CSR} \rightarrow \mathrm{BC}$, and CSR $\rightarrow$ PEWOM) are greater than 1,96 , i.e. statistically significant. These results in Table 2 and Figure 2 reveal that the impact of employee-oriented CSR on internal branding benefits is partially mediated by knowledge dissemination. The total effects of employee-oriented CSR on internal branding benefits are all positive. The results, therefore, support $\mathrm{H} 5-1, \mathrm{H} 5-2, \mathrm{H} 5-3$, and H5-4. 


\section{Discussion}

For life insurance companies with a large sales force, sustainable competitive advantage can be built by new approaches that are based on partnership between the organization and employees and at the same time incorporate values such as ethics, empathy, and connectedness, since the new challenges facing financial services companies include numerous scandals as well as allegations of treatment of their employees as mindless cogs in a machine (Ahmed \& Rafig, 2003). These challenges are observed not only in Taiwan, but all over the world. Our research project was thus designed to achieve a deeper understanding of the possibility of employing CEV and employee-oriented CSR as business levers of internal branding for life insurance industry.

The positive associations between ethics and internal branding benefits have often been verified in previous studies. However, van Der Merwe, Pitt \& Berthon (2003) point out that though favorable outcomes seem to imply a strong presence of CEV or ethical behavior in companies, the reverse is not always true. In other words, the direct causal influence of CEV on internal branding benefits may not exist, Our results indicate one possible way to solve this puzzle. As mentioned, the results given in Table 2 and Figure 2 show that CEV influences internal branding benefits only by way of other variables, such as knowledge dissemination. However, this finding does not deny a possible role for $\mathrm{CEV}$ in internal branding.

Our results show that for life insurance companies, employee-oriented CSR can significantly lead to internal branding benefits both directly and indirectly. Figure 2 illustrates additionally that all standardized direct effects are larger than standardized indirect effects. Therefore, for life insurance companies, employee-oriented CSR can be considered as one independent lever of internal branding and can be conducted without other auxiliary initiatives to induce internal branding benefits. Furthermore, because of the significant indirect effects of employee-oriented CSR on internal branding benefits, for sales managers of life insurance companies, it can be employed as an auxiliary lever to enhance the effect of conventional internal branding practices, such as knowledge dissemination, on internal branding benefits. Directing internal branding to pay more attention to employee-oriented CSR can complete successful reciprocal exchange relationships between sales forces and their life insurance companies and achieve sustainable competitive advantage for the organization as a whole.

As with any research, the current study has several limitations that point to many areas of future research on internal branding model incorporating CEV and CSR that would be of interest to marketing practitioners and academics.

First, future research could clarify the causal ordering of internal branding benefits. Because of the ambiguous casual ordering and for better illustration of the effects of CEV and employee-oriented CSR on internal branding benefits, the causal relationships between these benefits were ignored in the current study. Second, future research should supplement the cross-industrial or cross-national analysis. The sample under study is industry- and nation-specific (salespeople in the life insurance industry in Taiwan). Further research is needed to generalize our findings to other industries and countries. Finally, customer outcomes are not investigated directly. It appears that research needs to be elaborated more robustly through exploring the relationships between employee internal branding benefits and customer outcomes. Since the positive impacts of employee internal branding benefits on customer outcomes were verified by the literature regarding the service-profit chain (Homburg, Wieseke \& Hoyer, 2009), our results imply positive relationships between CEV, CSR and customer outcomes.

\section{References}

Ahmed, P.K. \& Rafig, M. 2003. 'Internal marketing issues and challenges', European Journal of Marketing, 37(9): 1177-1186.

Allen, N.J. \& Meyer, J.P. 1990. 'The measurement and antecedents of affective, continuance and normative commitment to the organization', Journal of Occupational Psychology, 63: 1-18.

Andrews, J.C., Netemeyer, R., Burton, S., Moberg, P. and Christainsen, A. 2004. 'Understanding adolescent intentions to smoke: An examination of relationships among social influences, prior trial behaviors, and antitobacco campaign advertising', Journal of Marketing , 68(4): 110-123.

Aselage, J. \& Eisenberger, R. 2003. 'Perceived organizational support and psychological contracts; a theoretical integration', Journal of Organizational Behavior, 24: 491-509.

Aurand, T.W., Gorchels, L. \& Bishop, T.R. 2005. 'Human resource management's role in internal branding: An opportunity for cross-functional brand message synergy', Joumal of Product \& Brand Management, 14(3): 163-169.

Bagozzi, R.P. \& Phillips, L.W. 1982. 'Representing and testing organizational theories: A holistic construal', Administrative Science Quarterly, 27(3): 459-489.

Bagozzi, R.P. \& Yi, Y, 1988. 'On the evaluation for structural equation models', Joumal of the Academy of Marketing Science, 16(1): 74-94.

Baker, T.L., Hunt, T.G. \& Andrews, M.C. 2006. 'Promoting ethical behavior and organizational citizenship behaviors: the influence of corporate ethical values', Journal of Business Ethics, 59(7): 849-857.

Baron, R.M. \& Kenny, D.A. 1986، 'The moderator-mediator distinction in social psychological research: conceptual, strategic, and statistical considerations", Journal of 
Personality and Social Psychology, 51(6): 1173-1182.

Bendixen, M. \& Abratt, R. 2007. 'Corporate identity, ethics and reputation in supplier-buyer relationships', Journal of Business Ethics, 76(1): 69-82.

Beneke, J., Wannke, N., Pelteret, E., Tladi, T. \& Gordon, D. 2012. 'Dont bank on it: Delineating the relationship between corporate social responsibility and retail banking affinity', South African Joumal of Business Management, 43(1): 4554.

Bollen, K.A. 1989. Structural equations with latent variables. New York: Wiley.

Burmann, C. \& König, V. 2011. 'Does internal branding really drive brand commitment in shared-service call centers ?'. Journal of Brand Management, 18(6): 374-393.

Burmann, C. \& Zeplin, S. 2005. 'Building brand commitment: a behavioural approach to internal branding', Joumal of Brand Management, 12(4): 279-300.

Burmann, C., Zeplin, S. \& Riley, N. 2009. 'Key determinants of internal branding success: An exploratory empirical analysis', Journal of Brand Management, 16(4): 264-284.

Coyle-Shapiro, I.A-M. \& Morrow, P.C. 2006. 'Organizational and client commitment among contracted employees, Journal of Vocational Behavior, 68(3): 416431.

de Chernatony, L. \& Cottam, S. 2006. 'Internal brand factors driving successful financial services brands", European Journal of Marketing, 40(5/6): 611-33.

Fornell, C. \& Larcker, D.F. 1981. 'Evaluating structural equation models with unobservable variables and measurement error ${ }^{*}$, Journal of Marketing Research, 18(1): $39-50$.

Galotti, K.M. 2008. Cognitive psychology - in and out of the laboratory. 4th Edition. Wadsworth, Belmont, CA: Thomson.

Guest, D.E. \& Conway, N. 2002. 'Communicating the psychological contract: an employer perspective', Human Resource Management Joumal, 12(2): 22-38.

Hackman, J.R. \& Oldham, G.R. 1975. 'Development of the job diagnostic survey", Journal of Applied Psychology, 60(2): $159-170$.

Heskett, J.L., Jones, T.O., Loveman, G.W., Sasser, W.E. Jr \& Schlesinger, L.A. 1994. 'Putting the service profit chain to work', Harvard Business Review, 72(2): 164-170.

Holmbeck, G.N. 1997. 'Toward terminological, conceptual, and statistical clarity in the study of mediators and moderators: Examples from the child-clinical and pediatric psychology literatures' Journal of Consulting and Clinical Psychology, 65(4): 599-610.

Homburg, C., Wieseke, J. \& Hoyer, W.D. 2009. 'Social identity and the service-profit chain", Joumal of Marketing, $73(2): 38-54$.

Hu, L.-T. \& Bentler, P.M. 1999. 'Cutoff criteria for fit indices in covariance structure analysis; Conventional criteria versus new alternatives, Structural Equation Modeling, 6(1): 1-55.

Hunt, S.D., Wood, V.R. \& Chonko, L.B. 1989. 'Corporate ethical values and organizational commitment in marketing', Joumal of Marketing, 53(3): 79-90.

Ind, N. 2003. 'Inside out: how employees build value', Journal of Brand Management, 10(6): 393-402.

Jones, E., Busch, P. \& Dacin, P. 2003. 'Firm market orientation and salesperson customer orientation: Interpersonal and intrapersonal influences on customer service and retention in business-to-business buyer-seller relationships', Joumal of Business Research, 56(4): 323340 .

Jöreskog, K. G. \& Sörbom, D. 1993. LISREL 8: Structural equation modeling with the SIMPLIS command language. Chicago: Scientific Software International.

Keller, K.L. 2001. 'Building customer-based brand equity', Marketing Management, 10(2): 14-19.

Kessler, I., Undy, R. \& Heron, P. 2004. "Employee perspectives on communication and cross-consultation: Findings from a cross-national survey,, International Journal of Human Resource Management, 15(3): 512-532.

King, C. \& Grace, D. 2010. 'Building and measuring employee-based brand equity', European Journal of Marketing, 44(7/8): 937-971.

Kline, R.B. 2005. Principles and Practice of Structural Equation Modeling. 2nd Edition. New York: The Guilford Press.

Lichtenstein, D.R., Drumwright, M.E. \& Braig, B.M. 2004. 'The effect of corporate social responsibility on customer donations to corporate-supported nonprofits', Journal of Marketing, 68(4): 16-32.

Maignan, I. \& Ferrell, O.C. 2001. 'Corporate citizenship as a marketing instrument: Concepts, evidence and research directions', European Journal of Marketing, 35(3/4): 457484.

Maignan, I., Ferrell, O.C. \& Hult, G.T.M. 1999. 'Corporate citizenship: Cultural antecedents and business benefits', Joumal of the Academy of Marketing Science, 27(4): 455469. 
Merz, M.A., He, Y. \& Vargo, S.L. 2009. 'The evolving brand logic: a service-dominant logic perspective", Journal of the Academy of Marketing Science, 37(3):328-345.

Miles, S. J. \& Mangold, G. 2004، 'A conceptualization of the employee branding process', Joumal of Relationship Marketing, 3(2-3):65-87.

Mohr, J., Fisher, R. \& Nevin, J. 1996. 'Collaborative communication in interfirm relationships. Moderating effects of integration and control', Journal of Marketing, 60(3): 103-115.

Mostovicz, I., Kakabadse, N. \& Kakabadse, A. 2009. 'CSR: The role of leadership in driving ethical outcomes", Corporate Governance, 9(4): 448-460.

Nguyen, N. \& Leblanc, G. 2002. 'Contact personnel, physical environment and the perceived corporate image of intangible services by new clients', International Journal of Service Industry Management, 13(3): 242-262.

Nunnally, J. C. \& Bernstein, I. H. 1994, Psychometric Theory. 3rd Edition. New York: McGraw-Hill.

Papasolomou, I. \& Vrontis, D. 2006. 'Building corporate branding through internal marketing: The case of the UK retail bank industry, Journal of Product \& Brand Management, 15(1): 37-47.

Pugh, S.D. 2001. 'Service with a smile: Emotional contagion in the service encounter", The Academy of Management Journal, 44(5): 1018-1027.

Ramlall, S. 2004. 'A review of employee motivation theories and their implications for employee retention within organizations', Joumal of American Academy of Business, $5(1 / 2): 52-63$.

Rego, A., Leal, S., Cunha, M.P., Faria, J. \& Pinho, C. 2010. 'How the perceptions of five dimensions of corporate citizenship and their inter-inconsistencies predict affective commitment", Journal of Business Ethics, 94(1): 107-127.

Richtermeyer, S.B., Greller, M.M. \& Valentine, S.R. 2006. 'Organizational ethics: measuring performance on this critical dimension', Management Accounting Quarterly, $7(3): 23-30$.

Robson, P.J.A. \& Tourish, D. 2005. 'Managing internal communication; An organizational case study, Corporate Communications: An Intemational Journal, 10(3); 213-22.

Schein, E.H. 1984. 'Coming to a new awareness of organizational culture', Sloan Management Review, 25(2): 3-16.

Schlager, T., Bodderas, M., Maas, P. \& Cachelin, J.L. 2011. 'The influence of the employer brand on employee attitudes relevant for service branding: An empirical investigation", Journal of Services Marketing, 25(7); 497-508.
Sims, R.R. 1991. 'The institutionalization of organizational ethics', Journal of Business Ethics, 10(7): 493-506,

Sobel, M.E. 1982. Asymptotic intervals for indirect effects in structural equations models. In Leinhart, S. (Ed.). Sociological Methodology. San Francisco: Jossey-Bass.

Tomezak, T., Herrmann, A., Brexendorf, T. \& Kernstock, J. 2005. Behavioral branding - Markenprofilierung durch persönliche Kommunikation', Thexis, 22(4): 28-31.

Torkzadeh, G., Koufteros, X. \& Pflughoeft, K. 2003. "Confirmatory analysis of computer self-efficacy", Structural Equation Modeling: A Multidisciplinary Journal, 10(2): 263-275.

Valentine, S.R., Godkin, L. \& Lucero, M. 2002. 'Ethical context, organizational commitment, and personorganization fit', Journal of Business Ethics, 41(4): 349360 .

Van Der Merwe, R., Pitt, L.F. \& Berthon, P. 2003. 'Are excellent companies ethical? Evidence from an industrial setting'. Corporate Reputation Review, 5(4): 343-355.

Vella, P.V., Gountas, J. \& Walker, R. 2009. 'Employee perspectives of service quality in the supermarket sector", Joumal of Services Marketing, 23(6): 407-421. 